\title{
Juridical Analysis Related To Confidentiality Of Notary Liability
}

\author{
D Djunaedi*) \\ ${ }^{* *}$ ) Faculty of Law, Universitas Islam Sultan Agung Semarang email \\ djunaedi@unissula.ac.id
}

\begin{abstract}
Notary protection related to confidentiality, especially in the law enforcement process, has not been able to materialize effectively. This is because there is no real protection system for notaries who reveal the confidentiality of their rights in the law enforcement process. This writing uses an empirical juridical method. As for the results of existing research, it can be found that the fact that the limitations of a notary in maintaining the confidentiality of a notary's duties based on the Notary's Position Law are that notaries must keep secrets related to their position. The notary is obliged to keep the contents of the act secret, even the notary is obliged to keep all information from the preparation of the deed to the completion of the drawing up of a deed and if he is made a witness in a case, can exercise his right to resign as a witness. However, it often happens that in a law enforcement process, a notary who is asked to assist in proof by disclosing the confidentiality of a deed that he has made can be sued and threatened by legal sanctions both in civil terms, namely acts against the law or for criminal reasons. Therefore, it is necessary to do more real legal protection for notaries who disclose the confidentiality of the deeds they have made for the sake of law enforcement.

Keywords: Position, Confidentiality, Notary, Juridical
\end{abstract}

\section{Introduction}

Notary as a public official who has special authority to make authentic deeds is seen as an honorable position in society. Based on this authority, the Notary is expected to be able to contribute to the creation of legal certainty through the authentic deed he makes. The Notary Deed plays an important role in determining clearly and clearly the legal rights and obligations of the parties contained in it. In addition, the Notary's authentic Deed is part of a state document which must be properly kept and kept secret by the Notary Public. Public officials are officials who carry out the profession in legal services to the community, in order to provide legal protection and guarantees in order to achieve legal certainty in society.

Thus, it can be said that a Notary as a public official is an official who carries out some of the state's public functions, especially in the field of civil law in making various authentic deeds in the field of general agreements and deeds in the field of other civil legal acts which are part of mandatory state documents, kept and kept confidential by a notary. The provisions of Article 1868 of the Civil Code require that authentic deeds must be made in the form stipulated by law and made by the competent official at the place where the deed was made. The authorized official referred to in Article 1868 of the Civil Code is the official who is given the authority to make the authentic deed. Notary is one of the public officials who have been determined by law is authorized to make authentic deeds. ${ }^{1}$ In addition to other officials, in this regard are officials of the population and civil registration services (Disdukcapil) in making authentic birth and death certificates, and marriage certificates,

\footnotetext{
${ }^{1}$ A.Kohar, 2013, Notaris Dalam Praktek Hukum, Alumni Bandung, p.64.
} 
Land Deed Making Officials (PPAT) in making land deeds that have registered rights, auction officials in making authentic deeds in the field of implementation of results, auction and others. Notary as a public official has the authority and obligations as stipulated in the Notary Office (UUJN). ${ }^{2}$

Besides having the authority as stated in UUJN and described above, notary as a public official also has the obligation to carry out his position as a general official who makes authentic deed. Notaries have the obligations stipulated in Article 16 UUJN in carrying out their positions such as: they are obliged to act trustworthy, honestly, thoroughly, independently, and protect the interests of the parties involved in legal actions, containing deeds in the form of Minuta deeds and keep them as a part of the Notary protocol, placing letters and documents as well as fingerprints on the Minuta deed, issuing grosse deeds, copies of deeds, or quotations of deeds based on Minuta deeds, providing legal services unless there is a reason to reject them, keeping everything about the deed and all information obtained for making deeds in accordance with the oath of office, unless the law stipulates otherwise, bind the deeds made within 1 (one) month into a book containing not more than 50 (fifty) deeds, and if the number of deeds cannot be contained in one book, the deed can be bound into more than one book, and recorded the minimum number of deeds, month and year of manufacture on the cover of each book, making a list of deeds of protest against non-payment or non-receipt of securities, making a list of deeds relating to wills according to the time order of making Deeds every month, sending a list of deeds or a list of nil with respect to with a will to the center of testament at the ministry that administers government affairs in the field of law within 5 (five) days in the first week of each following month, records in the reportorium the date of delivery of the will at the end of each month, has a stamp or stamp bearing the symbol of the Republic of Indonesia and in the circular room written the name, position and domicile of the person concerned, read out the Deed in front of the audience in the presence of at least 2 (two) witnesses, or 4 (four) special witnesses for making a will under hand, and signed at that moment by pengha dap, witnesses and notaries, accept candidates for Notary apprenticeship. The obligation to keep the Minuta Deed does not apply if the notary issues the Deed in originali.

Deed in originali includes deed of payment of rent, interest, and pension, deed of offering cash payment, deed of protest against non-payment or non-receipt of securities, deed of attorney, deed of ownership certificate, other deeds in accordance with statutory provisions. Deed in originali can be made more than 1 (one) duplicate, signed at the same time, form and content, provided that each deed is written the words: "Valid as One and One Applies to All". Deed in originali containing the power of attorney and the name of the recipient of the power of attorney which has not been filled can only be made in 1 (one) copy, the shape and size of the stamp shall be determined by a ministerial regulation, reading of the deed is not mandatory, if the applicant wants the deed not to be read out because the interviewer has read it himself, knowing, and understanding the contents provided that it is stated in the closing of the deed and on each page of the Minuta Deed initialed by the parties, witnesses and notaries. Provisions are exempted from reading the head of the deed, comparison, brief and clear explanation of the principal of the Deed and closing the deed. If one of the conditions is not fulfilled, the Deed concerned only has the

${ }^{2}$ GHS Lumban Tobing, 2002, Peraturan Jabatan Notaris, Erlangga, Jakarta, p.37. 
power of proof as an underhand deed. The provisions do not apply to making a will. When a notary takes an oath based on each religion and belief, since then the notary has the right to carry out his duties, obligations and authority to become a public official in making authentic deeds in almost all legal actions as long as the authentic deed is not given authority to other officials. Notaries are appointed and dismissed by the government (Minister of Law and Human Rights) as public officials, based on the principle of trust in carrying out some of the duties and authorities of the state in making authentic deeds which must be kept and kept secret as part of state documents. ${ }^{3}$

The description above means that the oath pronounced by the notary contains two things that must be understood:

- Vertically, the notary is obliged to be responsible to God, because the oath that the notary says is based on our respective religions, thus it means that everything that is done will be held accountable in the form that God wants.

- Vertically to the state and society, meaning that the State has given trust to the Notary to carry out as the State's duty in the field of Civil Law, such as in making evidence in the form of deeds that have perfect evidentiary power, and to people who have believed that Notaries can keep (as a secret) all information or utterances given before a Notary Public.

Article 16 paragraph 1 letter $f$ of the UUJN states that, "In carrying out his / her office, a Notary is obliged to keep secret everything concerning the deed he has drawn, and all information obtained for making deeds in accordance with the oath / promise of office, unless the law stipulates otherwise". Article 16 paragraph 1 letter $f$ above is the legal basis for the Notary to exercise the right of denial, namely the right not to provide information to remain silent with anyone as long as the information is related to information and data in the authentic deed that he makes, or other information related to data the clients he knew. All data and information of the interceptors is confidential data and information that must be safeguarded and kept by the notary as well as possible, because it is personal information and data. Notary's right to refuse or in Dutch is called verschoningrecht, and the obligation to refuse a Notary or in Dutch is called verschoningsplicht for providing information on the contents of a deed made by a Notary, except under a statutory order. As a public official who is appointed and dismissed by the state through the Minister of Law and Human Rights, a notary, apart from having the right of denial, must also stand in the interests of the state which refers to the public interest in order to complete the legal process in the judiciary, so as to produce fair, useful decisions and guarantee legal certainty. A notary who discloses the secret of his position related to the contents of the deed he has made due to a law order, should obtain legal protection from the state through legal instruments, both laws and state law enforcement officials, because the deed made by the Notary is included in the state document which must be properly stored and kept confidential. ${ }^{4}$

The obligation or right to refuse a Notary in carrying out his / her position as a public official is given by Article 16 paragraph 1 letter $f$ of the UUJN in principle to maintain the confidentiality of the parties relating to legal actions contained in the authentic deed made

\footnotetext{
${ }^{3}$ Abidin Murtama, 2012, Wewenang Tanggung Jawab Notaris Berdasarkan UUJN No. 30 Tahun 2004, Mitra Ilmu, Surabaya, p. 18.

${ }^{4}$ Syahrul Effendie, 2010, Notaris Dan Hukum Pidana, Lentera, Surabaya, p.12.
} 
by the Notary Public. The notary may not disclose the contents of the deed which is a legal act of the tappers to anyone, because the legal act is a secret between the parties whose names are contained in the authentic deed made by the notary. The confidentiality of the parties and their legal actions as stated in the authentic deed is one of the obligations promised by the Notary in pronouncing his oath of office before being appointed as Notary. The oath that has been pronounced is a promise that must be kept firm and must be carried out properly by a notary. ${ }^{5}$

This paper aims to analyze and describe the ineffective maintenance of the confidentiality of the notary's duties as mandated by Law Number 2 of 2014.

\section{Research Methods}

This type of research in this writing is a type of empirical juridical research or what is called field research, which examines the applicable legal provisions and what really happens in the society. ${ }^{6}$ Empirical juridical research is legal research regarding the enactment or implementation of normative legal provisions in action at any particular legal event that occurs in society. ${ }^{7}$

\section{Results and Discussion}

\subsection{Limitation of Notary in Maintaining the Confidentiality of Current Notary Public Duties}

In connection with this notary deed, the provisions of Article 1 point 7 of Law Number 2 of 2014 concerning Notary Office stipulate that notary deeds are authentic deeds made by or before a notary according to the forms and procedures stipulated in this law. Based on this provision, the deed made by (door) notary in notary practice is called Akta Relaas or Minuta Deeds which contains a description of the notary seen and witnessed by the notary himself at the request of the parties, so that the actions or deeds of the parties carried out are written in the form of Notarial Deed. ${ }^{8}$

Deeds made before a notary (ten overstaan) are called party deeds, which contain descriptions or information and statements of the parties given or told before a notary public. The parties wish that their description or statement is written in the form of a notarial deed. Furthermore, the provisions of Article 38 paragraph (3) letter c of the UUJN confirm that the contents of the deed are the wishes and will of the parties to case who appear before a notary public.

Thus, the contents of the deed are the wishes of the clients themselves, not the wishes or will of the notary, but the notary only frames it in the form of a notary deed in accordance with UUJN. Therefore, if the contents of the deed are disputed by the parties or other interested parties, this is related to the contents of the deed, which is their own problem. The wishes of the parties to case as stated in the deed materially are the wishes or will of the parties themselves, not the will of the notary, and the notary's duty is only to provide

\footnotetext{
${ }^{5}$ Soegondo R. Notodisorjo, 2010, Hukum Notariat di Indonesia (Suatu Penjelasan), Raja Grafindo Persada, Jakarta, p. 9.

${ }^{6}$ Suharsimi Arikunto, 2012, Prosedur Penelitiaan Suatu Pendekatan Praktek, Rineka Cipta, Jakarta, p. 126.

${ }^{7}$ Abdulkadir Muhammad, 2004, Hukum dan Penelitian Hukum, Citra Aditya Bakti, Bandung, pp. 134.

${ }^{8}$ Husni Thamrin, 2011, Pembuatan Akta Pertanahan Oleh Notaris, Laksbang Pressindo, yogyakarta, p. 25.
} 
advice. Even if the suggestion is later followed and stated in the deed, it is still the wish or will of the parties to case themselves. So, the deed made by or before a notary is the will or wish of the parties to case, not the wish of the notary. ${ }^{9}$

At the request and wish of the parties, the notary shall write it down in the form stipulated by law in the form of an authentic deed which has the power of perfect proof and is binding on the parties making it. The notary is obliged to keep secret everything that is told to him as a notary, even though some of it is not included in the deed. The notary is not free to tell what is told to him as a notary by his client during talks as preparation for making a deed, even though not everything is included in the deed. The obligation to keep it confidential, apart from being required by law, also by the interests of the notary itself. A notary who cannot limit himself will experience the consequences in practice, he will immediately lose public trust and he will no longer be considered a confidant (vertrouwenspersoon). ${ }^{10}$

Keeping the contents of the deed secret and the information both oral and written obtained for the making of the deed, makes it a secret of the position of a notary public. The obligation to keep secret deeds made by the Notary Officer who is ordered by the law (mandatory) is strengthened by the existence of a notary's oath / promise of office. In the oath of office of notary, it is conveyed that a Notary Public is obliged to carry out his position with trust, honesty, accuracy, independent, and impartial. A Notary Public Officer should have the characteristics of a general official, namely: ${ }^{11}$

- Trustworthy: can be trusted to carry out his duties, namely carrying out orders from the parties / people who want the notary to state his intentions and wishes in a deed and the parties put their signatures at the end of the deed.

- Be honest: don't lie or cover things up.

- Thorough: namely to be careful and thorough in drafting the editorial deed so as not to harm the parties.

- Independent: The notary decides that the deed has the proper legal structure and can provide legal counseling to clients.

- Not taking sides: neutral, not taking sides with one party.

- Maintain attitude, behavior and carry out obligations in accordance with the professional code of ethics, honor, dignity and responsibility as a Notary

- Carry out obligations in accordance with the professional code of ethics, honor, dignity and responsibility as a Notary by maintaining the dignity of the Notary Public, including not vilifying fellow Notary colleagues or tariff wars.

- Will keep secret the contents of deeds and information obtained in the implementation of office; Keep the contents of the deed secret and the information obtained, meaning that the notary must hear the client's information and wishes before putting it in the form of a deed. UUJN Article 16 paragraph 1 letter F UUJN No. 02 of 2014, which states that: "Keep everything about the deed made secret and all information obtained for

\footnotetext{
9 Mulyono, 2010, Kesalahan Notaris dalam Pembuatan Akta Perubahan dasar CV. Cakrawala Media, Yogyakarta, pp. 2.

10 lbid, pp. 10.

${ }^{11}$ Habib Adjie, 2009, Menoropong Khazanah Notaris dan PPAT Indonesia, Citra Aditya Bakti, Bandung, pp. 33- 
making deeds in accordance with the oath / promise of office, unless the law stipulates otherwise."

According to the results of interviews with Notaries/Land Title Registrar, it states that the confidentiality of notaries is regulated in Article 4 of the Notary Position Law (UUJN) concerning Oath of Office and Article 16 paragraph (1) letter ( $f$ ) of UUJN, where violations of the obligation to maintain confidentiality can be punished with a maximum imprisonment of nine months or a maximum fine of six hundred Rupiah as referred to in Article 322 of the Criminal Code. In addition, those who feel that their rights have been harmed due to violations of the obligation of confidentiality can file a lawsuit against the law demanding compensation to the official based on the provisions of Article 1365 in conjunction with Article 1366 of the Civil Code.

However, considering that one of the legal products produced by a notary is a notary deed which is an authentic deed that has perfect evidentiary power as long as it is not proven otherwise, it is not uncommon for notaries to intersect with legal processes and are asked to show documents in the notary protocol or be asked to provide information related to authentic deeds made by notaries whether in civil, criminal, state administration or other court proceedings. ${ }^{12}$ The purpose of the request to show or provide documents in the notary's protocol or notary's summons in some cases is due to parties denying or questioning the authenticity of a notary deed made by the notary concerned.

In terms of a notary is requested by third parties including law enforcement officials to provide information related to the deed he has made and is asked to show the minimum deed or documents related to the requested deed which is involved in a case / dispute, things that must be kept confidential by the notary, namely The scope (object) of the secrecy of the notary's position can be seen in the oath of office of notary as regulated in Article 4 of the UUJN which says that the Notary takes an oath to keep secret "the contents of the deed and the information obtained in the exercise of the notary office", which is then reaffirmed in Article 16 paragraph (1) letter (f) UUJN in conjunction with the elucidation of Article 16 paragraph (1) letter (f) which reads as follows: Article 16 (1) In carrying out his position, a Notary is obliged to:... f. keep everything concerning the Deed he has made and all information obtained for the making of the Deed in accordance with the oath / promise of office, unless the law stipulates otherwise; Elucidation of Article 16 (1)... f. The obligation to keep everything related to the Deed and other documents confidential is to protect the interests of all parties related to the Deed.

From the two articles mentioned above, it can be concluded that the object of the notary's confidentiality obligation covers the following two things:

- everything regarding deeds made by a notary; and

- all information obtained in order to draw up the deed in order to protect the interests of all parties related to the deed.

Thus, a notary in his position is not allowed to disclose the confidential information attached to his position either by providing information about the deed and information obtained for making the deed or by showing, notifying, publishing or submitting quotations, copies, certificates and other documents related to the deed. unless the law regulates otherwise.

12 Interview with Notary / PPAT, Dipo Adi Wibowo, December 19, 2020. 


\section{Legal Protection Guarantee for Notaries Regarding the Confidentiality of the Position of Notary Public}

Notary in his position as a public official and at the same time as a profession is tasked with making written evidence in the form of authentic deeds that can create strong and perfect legal evidence. For this reason, a Notary in carrying out a secret of office needs to be given legal protection, in order to: ${ }^{13}$

- maintain the nobility, dignity, and honor of the position of a notary including when giving testimony and processing the examination at trial;

- keep the contents of the deed secret and all information obtained for making the deed; and

- keep the Minuta or documents that are attached to the Minuta Deed or Protocol of Notary which is in the keeper of the Notary.

As a form of legal protection for Notaries in carrying out occupational secrets, in general it has been regulated in general regulations, as stated in the following statutory provisions: ${ }^{14}$

- Article 1909 paragraph (2) point 3e of the Civil Code, which reads: "Anyone who because of his position, job or position according to law is obliged to keep something secret, but only solely regarding matters whose knowledge is entrusted to him as a thus."

- Article 146 paragraph (1) point 3e Herzien Inlandsch Reglement (HIR), which reads: "All persons who because of their legal position or position are obliged to keep secret positions; but solely on such matters which are entrusted to him."

- Article 277 paragraph (1) Herzien Inlandsch Reglement (HIR), which reads: "Persons, who are obliged to keep secrets because of their position, occupation, or legal position can ask to resign from testifying; but only of that which was known and entrusted to him. "

- Article 170 paragraph (1) of the Criminal Procedure Code, reads: "Those who because of their work, dignity or position are obliged to keep secrets, can ask to be exempted from the obligation to testify as witnesses, namely regarding matters entrusted to them."

Legal protection for Notaries in carrying out occupational secrets apart from being generally regulated has also been specifically regulated in the following statutory regulations: ${ }^{15}$

- Article 17 paragraph (1) and paragraph (2) of Law No. 48 of 2009 concerning Judicial Power, which reads:

1) The party being tried has the right to deny the judge hearing the case.

2) The right to deny as referred to in paragraph (1) is the right of a person being tried to file an objection accompanied by reasons against a judge hearing the case.

- Article 66 paragraph (1) and paragraph (3) of Law No. 30 of 2004 which has been amended by Law no. 2 of 2014 concerning the Position of Notary Public, which reads:

1) For the purposes of the judicial process, investigators, public prosecutors, or judges with the approval of the Notary Honorary Council which has the authority:

\footnotetext{
13 Habib Adjie, Muhammad Hafidh dan Zul Fadli, 2016, Himpunan Putusan Mahkamah Konstitusi Republik Indonesia Mengenai Undang-Undang Jabatan Notaris (UUJN), CV. Duta Nusindo Semarang, Semarang, p. 2.

${ }^{14}$ Ibid, p.4.

${ }^{15}$ Opcit, p 8.
} 
a) take a photocopy of the Minuta Deed and / or letters attached to the Minuta Deed or Notary Protocol in the Notary's deposit;

b) summon the Notary Public to be present in the examination relating to the Notary Deed or Protocol that is in the Notary's custody.

2) The Notary Honorary Council within 30 (thirty) working days from the receipt of the request for approval as referred to in paragraph (1) is obliged to provide an answer to accept or reject the request for approval.

In addition to having the Right to Remind, on the other hand, notaries have an obligation to keep the contents of the deed secret and all information obtained in making deeds as regulated in Article 16 paragraph (1) letter $f$ of the UUJN.

Article 54 paragraph (1) UUJN states that a Notary can only give, show, or notify the contents of the deed, grosse deed, a copy of the deed, or an excerpt of the deed, to people with direct interest in the deed, heirs, or people who obtain rights, unless specified other by statutory regulations. In addition to the aforementioned provisions, the notary under oath will keep the contents of the deed and the information obtained in the exercise of his office confidential. ${ }^{16}$

Based on the results of an interview with a Notary Public / Land Titles Registrar, in providing information to investigators, the Notary cannot ignore the oath of office as a Notary. Therefore, it is important for notaries and investigators to understand the contents of the confidentiality held by a notary office. So that the Notary can provide information without neglecting the confidentiality of the Notary's position on the deed made by the Notary.

Notaries are public officials who have been given legal protection by law in order to give testimony before the court. The legal protection provided by this law is the right of denial. The right to deny, or also known as the right to refuse or the right to ask to be released as a witness, exists in several positions, which are granted by law. The rejection is not only limited to what is stated in the deed he makes, but the whole facts related to the deed. The right to refuse is a consequence of the obligation to keep secret something that is known. ${ }^{17}$

Based on the results of the interview, the writer analyzes that Notary is obliged to keep secret, not only for the things that are stated in the deed (content of the deed), but also for everything that is notified or conveyed to him as a Notary or that he knows because of his position, even though it is not included in the deed. Based on the Right of Refusal, the Notary Public can exercise his right to resign as a witness by demanding the use of the Right of Refusal.

The right of refusal, which in fact is the right inherent in the notary public, in terms of the examination process, be it the level of investigation, investigation or trial process, the attitude of a notary is passive. The point is that, in order to provide information at trial, notaries may only provide information in the extent of technical matters relating to the implementation of their position. Not in providing information regarding the contents of the deed wished by the parties. The obligation to keep this secret is not only to keep the secrets of the parties that are stipulated in the deed, but also in order to maintain the honor and dignity of a notary in carrying out his profession.

\footnotetext{
${ }^{16}$ Law Number 02 of 2014 concerning Amendments to Law Number 30 of 2004 concerning the Position of Notary Public.

17 Interview with Notary / PPAT, Dipo Adi Wibowo, December 19, 2020.
} 


\section{Clossing}

The limitations of a notary in maintaining the confidentiality of a notary's duties based on the Law on Notary's Position are that notaries must keep confidential what is related to their position. The notary is obliged to keep the contents of the act secret, even the notary is obliged to keep all information from the preparation of the deed to the completion of the drawing up of a deed and if he is made a witness in a case, can exercise his right to resign as a witness. However, it often happens that in a law enforcement process, a notary who is asked to assist in proof by disclosing the confidentiality of a deed that he has made can be sued and threatened by legal sanctions both in civil terms, namely acts against the law or on criminal grounds. So it is necessary to do more real legal protection for notaries who disclose the confidentiality of the deeds they have made for the sake of law enforcement.

\section{References}

[1] Abdulkadir, Muhammad, 2004, Hukum dan Penelitian Hukum, Citra Aditya Bakti, Bandung

[2] Adjie, Habib, 2009, Menoropong Khazanah Notaris dan PPAT Indonesia, Citra Aditya Bakti, Bandung,

[3] Adjie, Habib; Muhammad Hafidh and Zul Fadli, 2016, Himpunan Putusan Mahkamah Konstitusi Republik Indonesia Mengenai Undang-Undang Jabatan Notaris (UUJN), CV. Duta Nusindo Semarang,

[4] Arikunto, Suharsimi, 2012, Prosedur Penelitiaan Suatu Pendekatan Praktek, Rineka Cipta, Jakarta

[5] Effendie, Syahrul, 2010, Notaris Dan Hukum Pidana, Lentera, Surabaya

[6] Kohar, A., 2013, Notaris Dalam Praktek Hukum, Alumni Bandung

[7] Lumban Tobing, GHS, 2002, Peraturan Jabatan Notaris, Erlangga, Jakarta

[8] Murtama, Abidin, 2012, Wewenang Tanggung Jawab Notaris Berdasarkan UUJN No. 30 Tahun Tahun 2004, Mitra Ilmu, Surabaya

[9] Mulyono, 2010, Kesalahan Notaris dalam Pembuatan Akta Perubahan dasar CV. Cakrawala Media, Yogyakarta

[10] R. Notodisorjo, Soegondo, 2010, Hukum Notariat di Indonesia (Suatu Penjelasan), Raja Grafindo Persada, Jakarta

[11] Thamrin, Husni, 2011, Pembuatan Akta Pertanahan Oleh Notaris, Laksbang Pressindo, Yogyakarta 